\title{
Pengaruh Capital Intensity, Karakteristik Perusahaan, Dan CSR Disclosure Terhadap Penghindaran Pajak pada Perusahaan Manufaktur
}

\author{
Anita Ade Rahma ${ }^{*}$, Nila Pratiwi ${ }^{2}$, Hilda Mary ${ }^{3}$, Indriyenni ${ }^{4}$ \\ Universitas Putra Indonesia "YPTK", Padang \\ anita_aderahma@upiyptk.ac.id, nilapratiwi8@gmail.com, hildamary@upiyptk.ac.id, \\ indriyenni@gmail.com
}

*Corresponding Author

Diajukan : 25 Nopember 2021

Disetujui : 15 Desember 2021

Dipublikasi : 6 Januari 2022

\begin{abstract}
This study aims to determine the effect of capital intensity, company characteristics, and disclosure of corporate social responsibility on tax avoidance with leverage as a moderating variable in manufacturing companies listed on the Indonesia Stock Exchange in the period 2015-2017. The sample in this study was taken by purposive sampling method in manufacturing companies listed on the Indonesia Stock Exchange in the period 2015-2017. The number of samples used was 82 companies. The method of analysis of this study is multiple linear regression using eviews 9.

The results showed that the intensity of capital had a positive and significant effect on tax avoidance, the company's characteristics had a negative and significant effect on tax avoidance, the disclosure of corporate social responsibility had a positive effect and not significant impact on tax avoidance. Leverage is able to moderate the influence of capital intensity on tax avoidance, leverage is able to moderate the effect of corporate characteristics on tax avoidance while leverage is not a variable that is able to moderate the disclosure effect of corporate social responsibility on tax avoidance. Finally, the authors suggest that tax avoidance considerations can be used other than those used by researchers. For the calculation of capital intensity, company characteristics, and disclosure of CSR can use other proxy proxies other than those used by researchers. And for the next researcher, it is expected to be able to add variables related to the variables affected, and extend the research period.
\end{abstract}

Keywords: capital intensity;, company characteristics; disclosure; corporate social responsibility, tax avoidance

\section{PENDAHULUAN}

Pajak merupakan kontribusi wajib oleh pemerintah yang harus dikeluarkan dan bersifat memaksa kepada warga Negara dan badan (perusahaan) bahwa sipembayar atau wajib pajak tidak mendapat imbalan secara langsung namun pajak tersebut digunakan pemerintah untuk keperluan Negara (kemakmuran rakyat) berdasarkan UU KUP Nomor 28 tahun 2007 pasal 1 ayat 1. Pajak merupakan beban yang harus dikeluarkan perusahaan yang secara otomatis mengurangi pendapatan perusahaan. Perusahaan menginginkan beban pajak yang rendah bahwa dengan beban pajak yang rendah mempengaruhi jumlah laba yang akan dihasilkan. Dalam melakukan perhitungan dan pembayaran pajak, pihak manajemen perusahaan melakukan upaya-upaya agar beban yang ditimbulkan dari pajak dapat ditekankan sekecil mungkin untuk memperoleh peningkatan laba bersih setelah dibebankan ke pajak. Sedangkan pemerintah menginginkan pajak yang tinggi.

Pajak dipandang sebagai suatu yang tidak menguntungkan bagi perusahaan Siregar (2016). Sesuatu yang tidak menguntungkan ini biasanya mendorong adanya upaya untuk melakukan penghindaran atau perlawanan pajak. Tindakan penyelewangan dan penghindaran merupakan salah 
satu bentuk dari perlawanan terhadap pajak. Menghindari pajak untuk meminimumkan kewajiban pajak dapat dilakukan dengan berbagai cara, baik yang masih memenuhi ketentuan perpajakan maupun yang melanggar peraturan perpajakan. Istilah yang sering digunakan adalah tax avoidance.

Menurut Rizki (2015), praktik penghindaran pajak (tax avoidance), wajib pajak tidak secara jelas melanggar undang-undang atau menafsirkan undang-undang namun tidak sesuai dengan maksud dan tujuan undang-undang. Praktik penghindaran pajak yang dilakukan oleh manajemen suatu perusahaan semata-mata untuk meminimalisasi kewajiban pajak yang dianggap legal, membuat perusahaan memiliki kecenderungan untuk melakukan berbagai cara untuk mengurangi beban pajaknya. Oleh karena itu persoalan penghindaran pajak merupakan persoalan yang unik dan rumit karena disatu sisi penghindaran pajak tidak melanggar hukum, tapi disisi lain penghindaran pajak tidak diinginkan oleh pemerintah.

Menurut Muzaki (2015), penghindaran pajak (tax avoidance) adalah usaha wajib pajak untuk meminimalkan beban pajak dengan cara menggunakan alternative-alternatif yang rill yang dapat diterima. Perusahaan merupakan salah satu dari wajib pajak selain daripada masyarakat di Indonesia. Pajak yang dibayarkan perusahaan berasal dari laba yang diperoleh perusahaan kemudian dikurangkan dengan pajak, semakin besar perolehan laba yang diperoleh maka semakin besar pajak yang dibayarkan perusahaan.

Menurut Nurjanna (2017), adapun factor-faktor yang mempengaruhi penghindaran pajak (tax avoidance) antara lain konservatisme akuntansi, intensitas modal, komisaris independen, dan karakteristik perusahaan. Sedangkan menurut Rizki (2015), factor-faktor yang mempengaruhi penghindaran pajak (tax avoidance) adalah corporate social responsibility dan capital intensity.

Menurut Nurjanna (2017), Capital intensity (intensitas modal) adalah besarnya investasi asset pada asset tetap perusahaan. Intensitas modal mencerminkan seberapa besar modal yang di butuhkan perusahaan untuk menghasilkan pendapatan yang diperoleh dari penurunan aktiva tetap atau peningkatan aktiva tetap. Intensitas modal didefenisi sebagai rasio antara aktiva tetap seperti peralatan, mesin dan berbagai properti terhatap total aktiva. pemanfaatan pengurangan perpajakan dapat dilakukan perusahaan yang memilih investasi dalam bentuk aset ataupun modal dalam hal depresiasi. Perusahaan yang berinvestasi dalam bentuk aset tetap dapat menjadikan biaya depresiasi sebagai biaya yang dapat di kurangkan dan pada akhirnya dapat mengurangi jumlah pajak yang harus dibayar perusahaan.

Menurut Siregar (2016), karakteristik perusahaan adalah ciri khas suatu entitas usaha. Karakteristik tersebut bisa dilihat dari jenis usahanya, ukuran perusahaan, tingkat profitabilitas, tingkat likuiditas dan keputusan investasi. Selain pemimpin perusahaan, karakteristik perusahaan juga menjadi salah satu factor penentu dalam pengambilan tindakan tax avoidance. Jadi dengan adanya perbedaan antara jenis usaha, ukuran perusahaan, tingkat profitabilitas, tingkat likuiditas dan keputusan investasi ini akan mempengaruhi tingkat penghidaran pajak (tax avoidance) di tiaptiap perusahaan yang berbeda-beda pula.

Tanggung jawab social perusahaan atau Corporate Social Responsibility (CSR) disebut sebagai komitmen bisinis berkelanjutan yang berkontribusi bagi ekonomi dan berpengaruh pada lingkungan sekitar dan masyarakat umum untuk meningkatkan kualitas sarana dan keberlansungan hidup masyarakat (Rahma \& Aldi, 2020). Dari defenisi tersebut dapat disebutkan bahwa pajak dan CSR sama-sama ditujukan untuk kesejahteraan umum. Namun bedanya adalah pajak dikelola oleh pemerintah pusat maupun daerah yang kemudian didistribusikan kepada masyarakat umum sedangkan biaya pelaksanaan CSR dikelola perusahaan untuk kemudian didistribusikan kepada masyarakat umum (Hidayati, 2017).

Kondisi keuangan berikutnya yang di peridiksi akan mempengaruhi penghindaran pajak (tax avoidance) adalah leverage. Leverage merupakan tindakan hutang yang digunakan perusahaan dalam melakukan pembiayaan. Noviari (2017) menyebut bahwa dari tahun 2000 hingga 2009, tingkat leverage perusahaan manufaktur yang go public di Indonesia cenderung mengalami peningkatan. Dalam kaitannya dengan pajak, apabila perusahaan memiliki kewajiban pajak tinggi maka perusahaan akan memiliki utang yang tinggi pula. Oleh sebab itu perusahaan akan berusaha melakukan penghindaran pajak.

Penelitian ini termotivasi dari penelitian sebelumnya yang meneliti tentang hubungan konservatisme, intensitas modal dan penghindaran pajak. Peneliti tertarik memodifikasi variabel 
intervening menjadi variabel moderating dengan menambahkan karakteristik perusahaan dan pengungkapan CSR sebagai pengaruh penghindaran pajak. Tujuan dalam penelitian ini untuk meneliti bagaimana sikap perusahaan dalam ketaatan membayar pajak.

Hasil penelitian Nurjannah (2017) yang menguji tentang pengaruh konservatisme akuntansi dan intensitas modal terhadap penghindaran pajak menunjukan konservatisme berpengaruh positif dan signifikan terhadap penghindaran pajak. Intensitas modal berpengaruh positif dan signigfikan terhadap penghindaran pajak. Hasil penelitian Muzaki (2015) yang menguji tentang pengaruh corporate soccial responsibility dan capital intensity terhadap penghindaran pajak menunjukan corporate social responsibility berpengaruh negatif terhadap penghindaran pajak. Capital intensity berpengaruh positif dan signifikan terhadap penghindaran pajak. Hasil penelitian Wijayati, dkk (2016) yang menguji tentang pengaruh karakteristik perusahaan, GCG dan CSR terhadap penghindaran pajak menunjukan karakteristik perusahaan berpengaruh positif dan signifikan terhadap penghindaran pajak. GCG dan CSR berpengaruh negatif terhadap penghindaran pajak.

PT. RNI sebuah perusahaan yang bergerak dibidang jasa kesehatan terafiliasi perusahaan di singapura, namun memiliki aktivitas yang cukup banyak di Indonesia. Diduga perusahaan ini melakukan praktik penghindaran pajak. Secara badan usaha PT.RNI sudah terdaftar sebagai perseroan terbatas. Namun dari segi permodalan, perusahaan tersebut menggantungkan hidup dari hutang afliasi. Artinya, pemilik di singapura memberikan pinjaman kepada RNI di Indonesia.

Dalam laporan keuangan PT.RNI 2014, tercatat hutang sebesar Rp 20,4 miliar. Sementara, omset perusahaan hanya Rp 2,178 miliar. Belum lagi ada kerugian ditahan pada laporan tahun yang sama senilai Rp 26,12 miliar. Modus lain yang dilakukan PT.RNI yaitu memanfaatkan PP 46 tahun 2013 tentang PPh UMKM, dengan tarif PPh final 1\%. Terakhir, dua pemegang saham PT.RNI berkewarganegaraan Indonesia tidak melaporkan SPT pajak secara benar sejak 2007-2015. Adapun dua pemegang saham, yang merupakan orang singapura juga tidak membayarkan pajak penghasilannya, padahal memiliki usaha di Indonesia.

Dalam praktik penghindaran pajak, wajib pajak tidak secara jelas melanggar undang-undang atau menafsirkan undang-undang namun tidak sesuai dengan maksud dan tujuan undang-undang. Praktik penghindaran pajak yang dilakukan manajemen suatu perusahaan semata-mata untuk meminimalisasi kewajiban pajak yang dianggap legal membuat perusahaan memiliki kecendrungan untuk melakukan berbagai cara untuk mengurangi beban pajaknya.

\section{Penghindaran Pajak}

\section{STUDI LITERATUR}

Penghindaran pajak adalah usaha meringankan beban pajak dengan tidak melanggar undangundang. Penghindaran pajak (tax avoidance) adalah "arramgement of a transaction in order to abtain a tax advantage, benefit, or reduction in a manner uninteded by thetax law' Brown (2012). Dari defenisi penghindaran pajak tersebut dapat disimpulkan bahwa penghindaran pajak adalah usaha wajib pajak untuk meringankan beban pajak yang bersifat legal yang tidak melanggar undang-undang perpajakan. Resmi (2017) mendefenisikan penghindaran pajak adalah cara mengurangi pajak yang masih dalam batas ketentuan perundang-undangan perpajakan dan dapat dibenarkan. Dengan kata lain, tax avoidance itu sendiri merupakan upaya efisieni beban pajak dengan menghindari pengenaan pajak melalui transaksi yang bukan merupakan objek pajak. Misalnya, perusahaan mengubah tunjangan karyawan dalam bentuk uang menjadi pemberian natura karena bukan merupakan objek pajak pph pasal 21. Biasanya perusahaan melakukan strategi atau cara yang legal sesuai dengan aturan-aturan UU yg berlaku, namun dilakukan untuk memanfaatkn hal-hal yang sifatnya ambigu dalam UU sehingga dalam hal ini wajib pajak memanfaatkan celah-celah yang ditimbukan oleh adanya ambiguitas dalam UU perpajakan. Meskipun hal ini bisa jadi tidak melanggar hukum, namun sebenarnya bertentangan dengan dibuatnya perundang-undangan perpajakan.

\section{Intensitas Modal}

Menurut Nugraha dan Wahyu (2015), capital intensity atau rasio intensitas modal adalah 
aktivitas investasi perusahaan yang dikaitkan dengan investasi aset tetap dan persediaan intensitas modal merupakan salah satu bentuk keputusan keuangan. Keputusan tersebut di tetapkan oleh manajemen perusahaan untuk meningkatkan profitabilitas perusahaan (Mulyani, dkk., 2014). Rasio intensitas modal dapat menunjukan efesiensi penggunaan aktiva untuk menghasilkan penjualan Nurjana (2017). Menurut Pilanoria (2016;44), intensitas modal merupakan salah satu bentuk keputusan keuangan. Keputusan tersebut ditetapkan oleh manajemen perusahaan untuk meningkatkan profitabilitas perusahaan. Intensitas modal mencerminkan seberapa besar modal yang dibutuhkan perusahaan untuk menghasilkan pendapatan. Sumber dana atau kenaikan modal dapat diperoleh dari penurunan aktiva tetap (dijual) atau peningkatan aktiva tetap (pembelian). Hampir semua aset tetap mengalami penyusutan dan biaya penyusutan dapat mengurangi jumlah pajak perusahaan. Intensitas modal didefenisikan sebagai rasio antara aktiva tetap seperti peralatan, mesin dan berbagai properti terhadap total aktiva. Rasio ini menggambarkan seberapa besar aset perusaaan yang diinvestasikan dalam bentuk aktiva tetap.

Penelitian yang dilakukan oleh Dwilopa (2016) mengenai capital intensity dan penghindaran pajak menghasilkan bahwa intensitas modal mempengaruhi penghindaran pajak (tax avoidance). Dwilopa (2016) menyatakan bahwa investasi pada aset tetap yang tinggi mengakibatkan beban penyusutan pada aset tetap meningkat sehingga akan mempengaruhi pajak yang di bayarkan. Penelitian yang dilakukan oleh Zulaikha (2014), intensitas modal adalah jumlah aset tetap yang dimiliki perusahaan dibandingkan dengan total aset prusahaan. Aset tetap perusahaan memungkinkan perusahaan untuk mengurangi pajaknya akibat dari penyusutan yang muncul dari aset tetap setiap tahunnya, karena beban penyusutan berpengaruh sebagai penguran beban pajak. Penelitian yang dilakukan oleh Noor et al (2013) mengemukakan bahwa intensitas aset tetap berpengaruh negative terhadap ETR. Hal ini berarti intensitas modal memiliki pengaruh positif terhadap penghindaran pajak. Yang artinya semakin tinggi intensitas modal peusahaan maka semakin tinggi penghindaran paja perusahaan.

\section{H1: Diduga capital intensity berpengaruh signifikan terhadap penghindaran pajak.}

\section{Karakteristik Perusahaan}

Menurut Tawang (2017), karakteristik perusahaan merupakan ciri khas suatu entitas usaha. Ciri khas tersebut meliputi profitabilitas, ukuran perusahaan, keputusan investasi serta pertumbuhan perusahaan. Menurut Nurfatia (2015), Karakteristik perusahaan merupakan ciri khas atau sifat yang melekat dalam suatu entitas yang dapat dilihat dari berbagai segi, diantaranya jenis usaha atau industri, tingkat likuiditas, tingkat profitabilitas, ukuran perusahaan, keputusan investasi lain-lain. Menurut Elva (2017), karakteristik perusahaan adalah ciri khas suatu entitas usaha. Karakteristik tersebut bisa dilihat dari jenis usanya, ukuran perusahaan, tingkat profitabilitas, tingkat likuiditas dan keputusan investasi.

Penelitian yang dilakukan oleh Surbakti (2012), karakteristik perusahaan adalah suatu skala dimana dapat diklasifikasikan besar kecil perusahaan menurut berbagai cara, antara lain: total aktiva, long size, penjualan dan kapitalisasi pasar, dan lain-lain. Secara logika, tarif pajak yang besarakan semakin memperbesr jumlah pajak yang dibayar, sehingga akan semakin mendorong perusahaan untuk melakukan tindakan penghindaran pajak. Penelitian yang dilakukan oleh Willyza (2017), bahwa perusahaan yang besar akan semakin kompleks transaksinya sehingga akan semakin memanfaatkan celah untuk melakukan tindakan tax avoidance. Penelitian yang dilakukan oleh Daljono (2017), menyatakan bahwa semakin besar perusahaan maka akan semakin rendah ETR yang dimilikinya, hal ini dikarenakan perusahaan besar dianggap memiliki sumber daya untuk memanipulasi proses politik yang terjadi, atau menggunakan sumber daya yang ada untuk membuat perencanaan pajak yang baik, serta menjalankan aktivitasnya sedemikian rupa sehingga dapat mengoptimalkan tax savings.

H2: Diduga karakteristik perusahaan berpengaruh signifikan terhadap penghindaran pajak.

\section{Corporate Social Responsibility}

Menurut the world business council for sustainable development (WBCSD), corporate social responsibility adalah melanjutkan komitmen bisnis untuk berprilaku etis dan berkontribusi 
terhadap pembangunan ekonomi dengan meningkatkan kualitas hidup tenaga kerja dan keluarganyaserta komunitas setempat dan masyarakat luas. CSR adalah tanggung jawab sebuah organisasi terhadap dampak-dampak dari keputusan dan kegiatan-kegiatan pada masyarakat dan lingkungan yang diwujudkan dalam bentuk prilaku transparan dan etis yang sejalan dengan pembangunan berkelanjutan dan kesejahteraan masyarakat, mempertimbangkan harapan pemangku kepentigan, sejalan dengan hukum yang ditetapkan dan norma-norma perilaku internasional, serta terintergrasi dengan organisasi secara menyeluruh (Rahma \& Aldi, 2020).

Penelitian yang dilakukan oleh Supriyadi, (2015), perusahaan melakukan pengungkapan CSR untuk mendapatkan legitimasi positif dari masyarakat guna mempertahankan kelangsungan hidup perusahaan. Perusahaan dituutut untuk mampu melakukan aktivitasnya sesuai dengan nilai dan batasan norma yang berlaku di masyarakat. Penelitian yang dilakukan oleh Ratmono dan Sagala (2014), Perusahaan dengan reputasi yang baik akan mempertahankan reputasinya dengan melakukan tanggung jawab atas aktivitasnya dan tidak melakukan praktik tax avoidance. Hal tersebut menunjukan, pengungkapan CSR maka semakin rendah tingkat tax avoidance. Penelitian yang dilakukan oleh Dharma dan Noviari (2017), mengungkapkan perusahaan dengan kegiatan CSR yang bertanggung jawab memiliki kemungkinan lebih rendah untuk terlibat dalam praktik tax avoidance.Hal serupa diungkapkan oleh Hoi et al., (2013) yaitu perusahaan dengan kegiatan CSR yang tidak bertanggung jawab secara sosial memiliki keterlibatan dalam praktik tax avoidance.

H3: Diduga Pengungkapan corporate social responsilityi berpengaruh signifikan terhadap penghindaran pajak.

\section{Leverage}

Leverage merupakan proporsi total hutang terhadap rata-rata ekuitas pemegang saham. Rasio tersebut digunakan untuk memberikan gambaran mengenai struktur modal yang dimiliki perusahaan, sehingga dapat dilihat tingkat resiko tak tertagihnya suatu utang (Novrianto,2012). Menurut Wijaya (2012) perusahaan yang memiliki rasio leverage tinggi akan lebih sedikit mengunkapkan informasi tanggung jawab sosial, supaya dapat melaporkan laba sekarang yang lebih tinggi (mengurangi biaya pengungkapan).

Menurut Budiman dan Setiyono (2012), leverage merupakan sumber pendanaan perusahaan eksternal dari hutang, hutang yang dimaksud disini adalah hutang jangka panjang. Menurut Carolina et al (2014) leverage menunjukan sejauh mana aktiva perusahaan bibiayai dengan hutang. Hal ini berarti leverage akan menunjukan perbandingan sumber pembiayaan yang digunakan perusahaan untuk membiayai kegiatan usahanya, antara menggunakan uang dengan mengguanakan modal sendiri.

\section{METODE}

Penelitian ini berjenis deskriptif dan hubungan kausal. Menurut Nazir (2014), metode deskriptif adalah suatu metode dalam meneliti status kelompok manusia, suatu objek, suatu set kondisi, suatu sistem pemikiran, ataupun suatu kelas peristiwa pada masa sekarang. Menurut Sugiono (2012), hubungan kausal adalah hubungan yang bersifat sebab akibat. Jadi disini ada variable independen (variable yang mempengaruhi) dan dependen (dipengaruhi). Dalam penelitian ini, populasi yang penulis gunakan adalah perusahaan manufaktur yang terdaftar di Bursa Efek Indonesia periode 2015-2017 sebanyak 164 perusahaan. Dalam pelitian ini, peneliti menggunakan teknik purpose sampling. Sugiyono (2014) menjelaskan bahwa sampling purposive adalah teknik penentuan sampel dengan pertimbangan tertentu. Adapun kriteria sampel yang digunakan dalam penelitian ini adalah sebagai berikut :

Tabel 1. Penarikan sampel

\begin{tabular}{|c|c|c|}
\hline No & Kriteria perusahaan & Jumlah \\
\hline
\end{tabular}


Owner: Riset \& Jurnal Akuntansi

e-ISSN : 2548-9224 |p-ISSN : 2548-7507

Volume 6 Nomor 1, Januari 2022

DOI : https://doi.org/10.33395/owner.v6i1.637

\begin{tabular}{|c|l|c|}
\hline 1. & $\begin{array}{l}\text { Perusahaan yang terdaftar di BEI selama periode 2015-2017 sebagai perusahaan } \\
\text { manufaktur }\end{array}$ & 164 \\
\hline 2. & $\begin{array}{l}\text { Perusahaan Manufaktur yang tidak menerbitkan laporan keuangan tahunan } \\
\text { secara berturut-turutselama 2015-2017 }\end{array}$ & $(35)$ \\
\hline 3. & \begin{tabular}{l} 
Perusahaan yang listing di BEI dibawah tahun 2015 \\
\hline 4.
\end{tabular} & $\begin{array}{l}\text { Perusahaan manufaktur yang tidak menyediakan laporan keuangan sesuai } \\
\text { dengan variable penelitian }\end{array}$ \\
\hline Jumlah sampel penelitian & 82 \\
\hline
\end{tabular}

Sumber: data diolah penulis, 2021

Berdasarkan kriteria tersebut, maka dari 164 perusahaan manufaktur yang terdaftar di BEI dalam periode 2015-2017 terdapat 82 perusahaan yang akan digunakan sebagai sampel.

Tabel 2. Defenisi Operasional Variabel

\begin{tabular}{|c|c|c|c|c|}
\hline No & Variabel & $\begin{array}{c}\text { Defenisi Operasional } \\
\text { variabel }\end{array}$ & Perumusan & Sumber \\
\hline 1 & $\begin{array}{l}\text { Intensitas modal } \\
\quad(\mathrm{X} 1)\end{array}$ & $\begin{array}{l}\text { Intensitas } \\
\text { diproksikan menggunakan } \\
\text { rasio intensitas aset tetap. } \\
\text { Rasio intensitas aset tetap } \\
\text { mengambarkan rasio atau } \\
\text { proporsi aset tetap } \\
\text { perusahaan dari total aset } \\
\text { yang dimiliki sebuah } \\
\text { perusahaan }\end{array}$ & $\begin{array}{l}\text { Rasio Intensitas Aset } \\
\text { Tetap }= \\
\text { Total Aset Tetap } \\
\text { Total Aset }\end{array}$ & $\begin{array}{l}\text { Madz Rizki } \\
(2015)\end{array}$ \\
\hline 2 & $\begin{array}{l}\text { Karakteristik } \\
\text { perusahaan } \\
\quad(\mathrm{X} 2)\end{array}$ & $\begin{array}{l}\text { Ciri khas atau sifat yang } \\
\text { melekat dalam suatu entitas } \\
\text { yang dapat dilihat dari } \\
\text { berbagai segi. Karakteristik } \\
\text { perusahaan diproksikan } \\
\text { dengan ukuran perusahaan }\end{array}$ & $\begin{array}{l}\text { ukuran perusahaan } \\
\text { Size }=\text { Log natural } \\
\text { (total aset) }\end{array}$ & $\begin{array}{l}\text { Kurniasih, } \\
2013\end{array}$ \\
\hline 3 & $\begin{array}{l}\text { Pengungkapan } \\
\text { corporate social } \\
\text { responsibility } \\
\quad \text { (X3) }\end{array}$ & $\begin{array}{l}\text { pengungkapan CSR diukur } \\
\text { dengan metode analisi isi } \\
\text { (content analysis) terhadap } \\
\text { laporan tahunan (annual } \\
\text { report) perusahaan. }\end{array}$ & $\begin{array}{l}\text { Nilai } 1 \text { = } \\
\text { mengungkapkan CSR } \\
\text { Nilai } 0=\text { tidak } \\
\text { mengungkapkan CSR }\end{array}$ & $\begin{array}{l}\text { Hidayati, } \\
2017\end{array}$ \\
\hline 4 & $\begin{array}{l}\text { Penghindaran } \\
\text { pajak } \\
\text { (Y) }\end{array}$ & $\begin{array}{l}\text { suatu upaya yang dilakukan } \\
\text { perusahaan baik perusahaan } \\
\text { berskala besar maupun kecil, } \\
\text { dalam rangka memperkecil } \\
\text { atau meminimalkan jumlah } \\
\text { beban pajak yang akan } \\
\text { dibayarkan yang bersifat } \\
\text { legal dengan menggunakan } \\
\text { celah pada undang-undang } \\
\text { perpajakan yang berlaku }\end{array}$ & $\begin{array}{l}\text { ETR = } \\
\text { Beban pajak } \\
\text { Laba sebelum pajak }\end{array}$ & $\begin{array}{l}\text { aditama, dkk } \\
\text { (2014) }\end{array}$ \\
\hline 5 & $\begin{array}{l}\text { Leverage } \\
\quad \text { (var. } \\
\text { Moderating) } \\
\quad(\mathrm{Z})\end{array}$ & $\begin{array}{lcc}\text { proporsi total } & \text { hutang } \\
\text { terhadap rata-rata } & \text { ekuitas } \\
\text { pemegang } & \text { saham } & \end{array}$ & $\begin{array}{l}\text { Lev }= \\
\text { Total Kewajiban Jangka } \\
\text { Panjang } \\
\text { Total Aset Perusahaan }\end{array}$ & $\begin{array}{l}\quad \text { Setiawan } \\
(2010) \\
\text { dalamSuyanto } \\
(2012)\end{array}$ \\
\hline
\end{tabular}

Sumber: diolah penulis 2021

Analisis Regresi Linear Berganda

Analisis regresi linear berganda adalah hubungan secara linear antara dua atau lebih variabel independen $(\mathrm{X} 1, \mathrm{X} 2, \ldots . \mathrm{Xn})$ dengan variabel dependen $(\mathrm{Y})$. Analisis ini untuk mengetahui arah 
hubungan anatra variabel independen dengan variabel dependen apakah masing-masing variabel independen berhubungan positif atau negative dan untuk memprediksi nilai dari variabel dependen apabila nilai vaiabel independen mengalami kenaikan atau penurunan. Data yang digunakan biasanya berskala interval atau rasio. Dengan persamaan sebagai berikut :

$\mathrm{ETR}^{\prime}=\mathrm{a}+\mathrm{b} 1 \mathrm{X} 1+\mathrm{b} 2 \mathrm{X} 2+\mathrm{b} 3 \mathrm{X} 3+\mathrm{b} 4 \mathrm{X} 1 * \mathrm{Z}+\mathrm{b} 5 \mathrm{X} 2 * \mathrm{Z}+\mathrm{b} 6 \mathrm{X} 3 * \mathrm{Z}+\mathrm{b} 7 \mathrm{Z}+\mathrm{e}$

\section{Statistik Deskriptif}

\section{HASIL}

Setelah seluruh data dan informasi berhasil dikumpulkan maka tahapan pengolahan data dapat segera dilaksanakan. Proses pengolahan data dilakukan dengan bantuan program Eviews 9. Statistik deskriptif memberikan gambaran atau deskripsi suatu data yang dilihat dari nilai rata-rata, standar deviasi, maksimum dan minimum. Beradasarkan tahapan pengolahan data yang telah dilakukan diperoleh ringkasan statistik deskriptif dari masing-masing variabel penelitian yang digunakan seperti pada tabel 3 dibawah ini

Tabel 3. Uji Statistik Deskriptif

\begin{tabular}{|l|c|l|l|l|l|}
\hline & ETR & CI & KP & CSR & LEV \\
\hline Mean & -1.350036 & 0.399798 & 3.032350 & 0.990868 & -2.488413 \\
\hline Median & -1.386294 & 0.384769 & 3.028683 & 1.000000 & -2.407946 \\
\hline Maximum & 0.652325 & 0.952386 & 3.415758 & 1.000000 & -0.462035 \\
\hline Minimum & -4.605170 & 0.000771 & 1.043804 & 0.000000 & -4.605170 \\
\hline Std. Dev. & 0.678104 & 0.200765 & 0.344082 & 0.095344 & 1.059076 \\
\hline Skewness & -0.975556 & 0.182713 & -1.634428 & -10.32033 & -0.276783 \\
\hline Kurtosis & 7.420895 & 2.310324 & 8.416627 & 107.5092 & 2.217060 \\
\hline & & & & & \\
\hline Jarque-Bera & 213.0793 & 5.558841 & 365.2306 & 103552.4 & 8.389815 \\
\hline Probability & 0.000000 & 0.062074 & 0.000000 & 0.000000 & 0.015072 \\
\hline & & & & & \\
\hline Sum & -295.6578 & 87.55580 & 664.0847 & 217.0000 & -544.9625 \\
\hline Sum Sq. Dev. & 100.2418 & 8.786832 & 25.80951 & 1.981735 & 244.5179 \\
\hline & & & & & \\
\hline Observations & 219 & 219 & 219 & 219 & 219 \\
\hline
\end{tabular}

Sumber: diolah penulis, 2021

Berdasarkan Tabel 3 di atas menunjukkan bahwa dari 219 observasi, Y memiliki nilai minimum sebesar -4.605170 , dan nilai maksimum sebesar 0.652325 sedangkan nilai rata-rata (mean) dari variabel ini adalah sebesar -1.350036 dengan nilai tengah (median) sebesar -1.386294 dan nilai standar deviasi sebesar 0.678104. Variabel X1 memiliki nilai minimum sebesar 0.000771 , dan nilai maksimum sebesar 0.952386 sedangkan nilai rata-rata (mean) dari variabel ini adalah sebesar -0.399798 dengan nilai tengah (median) sebesar 0.384769 dan nilai standar deviasi sebesar 0.200765. Variabel X2 memiliki nilai minimum sebesar 1.043804, dan nilai maksimum sebesar 3.415758 sedangkan nilai rata-rata (mean) dari variabel ini adalah sebesar 3.032350 dengan nilai tengah (median) sebesar 3.028683 dan nilai standar deviasi sebesar 0.344082. Variabel X3 memiliki nilai minimum sebesar 1.000000, dan nilai maksimum sebesar 1.000000 sedangkan nilai rata-rata (mean) dari variabel ini adalah sebesar 1.000000 dengan nilai tengah (median) sebesar 1.000000 dan nilai standar deviasi sebesar 0.000000. Variabel Z memiliki nilai minimum sebesar -4.605170 , dan nilai maksimum sebesar -0.462035 sedangkan nilai rata-rata (mean) dari variabel ini adalah sebesar -2.488413 dengan nilai tengah (median) sebesar -2.407946 dan nilai standar deviasi sebesar 1.059076.

\section{Analisis Regresi Panel}


Owner: Riset \& Jurnal Akuntansi

e-ISSN : 2548-9224|p-ISSN : 2548-7507

Volume 6 Nomor 1, Januari 2022

DOI : https://doi.org/10.33395/owner.v6i1.637

Analisis regresi panel MRA digunakan untuk melihat pengaruh variabel independen intensitas modal $\left(\mathrm{X}_{1}\right)$, karakteristik perusahaan $\left(\mathrm{X}_{2}\right)$ dan pengungkapan CSR $\left(\mathrm{X}_{3}\right)$ dengan leverage (Z) sebagai variabel moderasi secara simultan terhadap variabel dependen penghindaran pajak (Y) dengan asumsi variabel independen lain dianggap konstan. Berikut diperoleh hasil tabel estimasi menggunakan aplikasi Eviews 9:

Tabel 4. Hasil Regresi Panel

\begin{tabular}{|c|c|c|c|c|}
\hline Variable & Coefficient & Std. Error & t-Statistic & Prob. \\
\hline $\mathrm{CI}$ & 0.190017 & 0.044170 & 4.301990 & 0.0000 \\
\hline KP & -0.087686 & 0.021075 & -4.160773 & 0.0000 \\
\hline CSR & 0.063837 & 0.048122 & 1.326561 & 0.1861 \\
\hline CI_LEV & -0.836395 & 0.256899 & -3.255730 & 0.0013 \\
\hline KP_LEV & 0.027174 & 0.008047 & 3.376772 & 0.0009 \\
\hline CSR_LEV & -0.209986 & 0.166574 & -1.260615 & 0.2088 \\
\hline$\overline{\mathrm{LEV}}$ & -0.018240 & 0.011637 & -1.567403 & 0.1185 \\
\hline $\mathrm{C}$ & 0.360408 & 0.065521 & 5.500635 & 0.0000 \\
\hline & Weighted & Statistics & & \\
\hline $\mathrm{R}$-squared & 0.123866 & \multicolumn{2}{|c|}{ Mean dependent var } & 0.753069 \\
\hline Adjusted R-squared & 0.094800 & \multicolumn{2}{|l|}{ S.D. dependent var } & 0.843091 \\
\hline S.E. of regression & 0.203381 & \multicolumn{2}{|l|}{ Sum squared resid } & 8.727775 \\
\hline F-statistic & 4.261529 & \multicolumn{2}{|l|}{ Durbin-Watson stat } & 1.139958 \\
\hline \multirow[t]{2}{*}{ Prob(F-statistic) } & 0.000200 & & & \\
\hline & \multicolumn{2}{|c|}{ Unweighted Statistics } & & \\
\hline R-squared & 0.001668 & \multicolumn{2}{|c|}{ Mean dependent var } & 0.318676 \\
\hline Sum squared resid & 11.80839 & \multicolumn{2}{|l|}{ Durbin-Watson stat } & 0.857394 \\
\hline
\end{tabular}

Sumber : data diolah penulis, 2021

Dari pengolahan data diatas, maka diperoleh persamaan regresinya sebagai berikut :

$$
\begin{aligned}
\mathrm{Y}= & 0.360408+0.190017\left(\mathrm{X}_{1}\right)-0.087686\left(\mathrm{X}_{2}\right)+0.063837\left(\mathrm{X}_{3}\right)-0.836395\left(\mathrm{X}_{1} * \mathrm{Z}\right)+0.027174 \\
& \left(\mathrm{X}_{2} * \mathrm{Z}\right)-0.209986\left(\mathrm{X}_{3} * \mathrm{Z}\right)-0.018240(\mathrm{Z})+\mathrm{e}
\end{aligned}
$$

Dari persamaan regresi berganda dapat disimpulkan bahwa : 
1. Nilai konstanta sebesar 0.360408 artinya jika intenistas modal $\left(\mathrm{X}_{1}\right)$, karakteristik perusahaan $\left(\mathrm{X}_{2}\right)$, dan pengungkapan CSR $\left(\mathrm{X}_{3}\right)$, selisih nilai mutlak intensitas modal dan leverage $\left(\mathrm{X}_{1} \mathrm{Z}\right)$, selisih nilai mutlak karakteristik perusahaan dan leverage $\left(\mathrm{X}_{2} \mathrm{Z}\right)$ selisih nilai mutlak pengungkapan CSR dan leverage $\left(\mathrm{X}_{3} \mathrm{Z}\right)$ dan leverage $(\mathrm{Z})$ diabaikan $(0)$, maka penghindaran pajak nilainya adalah sebesar 0.360408 .

2. Koefisien regresi variabel intensitas modal sebesar 0.190017 artinya jika intensitas modal meningkat satu satuan bobot dengan asumsi karakteristik perusahaan $\left(\mathrm{X}_{2}\right)$, dan pengungkapan CSR $\left(\mathrm{X}_{3}\right)$, selisih nilai multak intensitas modal dan leverage $\left(\mathrm{X}_{1} \mathrm{Z}\right)$, selisih nilai mutlak karakteristik perusahaan dan leverage $\left(\mathrm{X}_{2} \mathrm{Z}\right)$ selisih nilai multak pengungkapan CSR dan leverage $\left(\mathrm{X}_{3} \mathrm{Z}\right)$ dan leverage $(\mathrm{Z})$ diabaikan (0), maka penghindaran pajak nilainya adalah sebesar 0.190017 .

3. Koefisien regresi variabel karakteristik perusahaan -0.087686 artinya jika karakteristik perusahaan meningkat satu satuan bobot dengan asumsi intensitas modal $\left(\mathrm{X}_{1}\right)$, pengungkapan CSR $\left(\mathrm{X}_{3}\right)$, selisih nilai multak intensitas modal dan leverage $\left(\mathrm{X}_{1_{-}} \mathrm{Z}\right)$, selisih nilai karakteristik perusahaan dan leverage $\left(\mathrm{X}_{2} \mathrm{Z}\right)$ selisih nilai mutlak dan pengungkapan CSR dan leverage $\left(\mathrm{X}_{2} \mathrm{Z}\right)$ dan leverage $(\mathrm{Z})$ diabaikan $(0)$, maka penghindaran pajak nilainya adalah sebesar 0.087686 .

4. Koefisien regresi variabel pengungkapan CSR sebesar 0.063837 artinya jika pengungkapan CSR meningkat satu satuan bobot dengan intensitas modal $\left(\mathrm{X}_{1}\right)$, karakteristik perusahaan $\left(\mathrm{X}_{2}\right)$, selisih nilai multak intensitas modal dan leverage $\left(\mathrm{X}_{1} \mathrm{Z}\right)$, selisih nilai multak karakteristik perusahaan dan leverage $\left(\mathrm{X}_{2_{-}} \mathrm{Z}\right)$ selisih nilai multak pengungkapan CSR dan leverage $\left(\mathrm{X}_{3} \mathrm{Z}\right)$ dan leverage $(\mathrm{Z})$ diabaikan $(0)$, maka penghindaran pajak nilainya adalah sebesar 0.063837 .

5. Koefisien regresi variabel selisih nilai mutlak intensitas modal dan leverage sebesar 0.836395 artinya jika intensitas modal dan leverage meningkat satu satuan bobot dengan asumsi intensitas modal $\left(\mathrm{X}_{1}\right)$, karakteristik perusahaan $\left(\mathrm{X}_{2}\right)$, dan pengungkapan CSR $\left(\mathrm{X}_{3}\right)$, selisih nilai mutlak karakteristik perusahaan dan leverage $\left(\mathrm{X}_{2} \mathrm{Z}\right)$ selisi nilai mutlak pengungkapan CSR dan leverage $\left(\mathrm{X}_{3} \mathrm{Z}\right)$ dan leverage $(\mathrm{Z})$ diabaikan $(0)$, maka penghindaran pajak nilainya adalah sebesar 0.836395 .

6. Koefisien regresi variabel selisih nilai mutlak karakteristik perusahaan dan leverage sebesar 0.027174 artinya jika selisih nilai mutlak karakteristik perusahaan dan leverage meningkat satu satuan bobot dengan asumsi intensitas modal $\left(\mathrm{X}_{1}\right)$, karakteristik perusahaan $\left(\mathrm{X}_{2}\right)$, dan pengungkapan CSS $\left(\mathrm{X}_{3}\right)$, selisih nilai mutlak intensitas modal dan leverage $\left(\mathrm{X}_{1} \mathrm{Z}\right)$ selisih nilai mutlak pengungkapan CSRdan leverage $\left(\mathrm{X}_{3} \mathrm{Z}\right)$ dan leverage $(\mathrm{Z})$ diabaikan (0), maka penghindaran pajak nilainya adalah sebesar 0.027174 .

7. Koefisien regresi variabel selisih nilai mutlak pengungkapan CSR dan leverage sebesar 0.209986 artinya jika selisih nilai mutlak pengungkapan CSR dan leverage meningkat satu satuan bobot dengan asumsi intensitas modal $\left(\mathrm{X}_{1}\right)$, karakteristik perusahaan $\left(\mathrm{X}_{2}\right)$, dan pengungkpan CSR $\left(\mathrm{X}_{3}\right)$, selisih nilai multak intensitas modal dan leverage $\left(\mathrm{X}_{1} \mathrm{Z}\right)$, selisih nilai mutlak karakteristik perusahaan dan leverage $\left(\mathrm{X}_{2} \mathrm{Z}\right)$ dan leverage $(\mathrm{Z})$ selisih diabaikan (0), maka penghindaran pajak nilainya adalah sebesar 0.209986 .

8. Koefisien regresi variabel leverage -0.018240 artinya jika leverage meningkat satu satuan bobot dengan asumsi intensitas modal $\left(\mathrm{X}_{1}\right)$, karakteristik perusahaan $\left(\mathrm{X}_{3}\right)$ pengungkapan CSR $\left(\mathrm{X}_{3}\right)$, selisih nilai mutlak intensitas modal dan leverage $\left(\mathrm{X}_{1} \_\mathrm{Z}\right)$, selisih nilai mutlak karakteristik perusahaan dan leverage $\left(\mathrm{X}_{2} \mathrm{Z}\right)$ dan selisih nilai mutlak pengungkapan CSR dan leverage $\left(\mathrm{X}_{3} \mathrm{Z}\right)$ diabaikan $(0)$, maka penghindaran pajak nilainya adalah sebesar 0.018240 . 


\section{Pengaruh intensitas modal terhadap penghindaran pajak}

Dari hasil uji t diketahui t statistik dari variabel intensitas modal adalah 4.301990 dengan tingkat signifikan $(0.000<0,05)$ intensitas modal berpengaruh terhadap penghindaran pajak. Dengan demikian Ho ditolak dan Ha diterima.

Bahwa semakin besarnya investasi aset dalam aset tetap akan mempengaruhi perusahaan dalam penghindaran pajak.

Variabel intensitas modal memiliki pengaruh yang signifikan terhadap penghindaran pajak dengan arah positif. Nilai koefesien yang positif menunjukan bahwa perusahaan lebih banyak menginvestasikan modalnya pada aset tetap akan memiliki tarif pajak efektif yang rendah. Jika tarif pajak efektif turun, maka discretionary tax avoidance akan naik. Hal ini dikarenakan beban depresiasi dari aset tersebut lebih besar sehingga beban perusahaan juga akan besar.

Berdasarkan agensi teori yang mengambarkan bahwa pihak manajemen lebih banyak mengetahui keadaan keuangan perusahaan yang sebenarnya sedangkan pihak berkepentingan lainnya tidak. Lebih lanjut, besar andil pihak manajemen perusahaan untuk mengalokasikan investasi asetnya dalam bentuk aset tetap sehingga beban depresiasi akan mempengaruhi laba perusahaan yang berujung pada praktik penghindaran pajak.

Hasil yang diperoleh ini sejalan dengan hasil penelitian dari Nurjannah (2017) yang mengatakan bahwa intensitas modal berpengaruh signifikan terhadap penghindaran pajak. Dan hasil yang diperoleh ini juga sejalan dengan hasil penelitian Kuriah dan Nur (2016) yang mendapatkan hasil bahwa intensitas modal tidak berpengaruh signifikan terhadap penghindaran pajak. Dengan demikian besar atau kecilnya investasi aset dalam aset tetap belum tentu mempengaruhi perusahaan dalam penghindaran pajak.

\section{Pengaruh karakteristik perusahaan terhadap penghindaran pajak}

Dari hasil uji t diketahui $t$ statistik dari variabel karakteristik perusahaan adalah --4.160773 dengan tingkat signifikan $(0.000<0,05)$ karakteristik perusahaan pengaruh terhadap penghindaran pajak. Dengan demikian Ho ditolak dan Ha diterima. Hasil ini dimungkinkan karena perusahaan yang besar mampu untuk mengatur perpajakan dengan melakukan perencanaan pajak sehingga dapat tercapainya penghematan pajak yang optimal. Dalam kasus ini penghematan pajak menggambarkan penghindaran pajak yang dilakukan perusahaan dengan cara yang legal. Dengan demikian pajak yang dibayarkan akan lebih kecil, sehingga besarnya TPE perusahaan lebih kecil dan dapat diambil kesimpulan bahwa discretinary tax avoidance naik.

Hal tersebut juga didukung dengan teori kekuasaan politik yang menjelaskan bahwa perusahaan yang besar akan memiliki sumber daya yang besar untuk mempengaruhi proses politik yang dikehendaki dan menguntungkan perusahaan termasuk perencanaan pajak, sehingga mereka dapat melakukan aktivitas penghindaran pajak untuk mencapai optimal penghematan pajak (Wijayanti, 2016).

Hasil ini sejalan dengan hasil yang didapatkan oleh Wijayanti (2016) dimana penelitiannya mengatakan bahwa karakteristik perusahaan berpengaruh terhadap penghindaran pajak. Dan juga sejalan dengan penelitian Anita (2016) yang mengatakan bahwa karakteristik perusahaan berpengaruh terhadap penghindaran pajak. Dengan demikian karakteristik dari suatu perusahaan belum tentu mempengaruhi suatu perusahaan dalam penghindaran pajak.

\section{Pengaruh pengungkapan CSR terhadap penghindaran pajak}

Dari hasil uji t diketahui t statistik dari variabel pengungkapan CSR adalah 1.326561 dengan tingkat signifikan $(0.1861>0,05)$ pengungkapan CSR tidak pengaruh terhadap penghindaran pajak. Dengan demikian Ho diterima dan Ha ditolak. Ketika perusahaan semakin tinggi tingkat pengungkapan CSR yang dilakukan, maka semakin rendah tingkat penghindaran pajak. Isu yang paling signifikan yang timbul dalam upaya menerapkan prinsip-prinsip CSR untuk pajak perusahaan meliputi tindakan-tindakan yang dapat menurangi kewajiban pajak perusahaan melalui penghindaran pajak perusahaan dan perencanaan pajak (Lanis,2016).

Hasil ini sejalan dengan penelitian Ajeng (2016) yang mengatakan bahwa pengungkapan CSR tidak berpengaruh signifikan terhadap penghindaran pajak. Hasil yang samajuga didapatkan oleh Naniek (2017) yang mengatakan bahwa pengungkapan CSR tidak berpengaruh terhadap penghindaran pajak. Dengan demikian apabila semakin tinggi tingkat pengungkapan CSR yang dilakukan maka semakin rendah tingkat penghindaran pajaknya. 


\section{Pengaruh intensitas modal terhadap penghindaran pajak dengan Leverage sebagai pemoderasi}

Dari hasil uji $\mathrm{t}$ diketahui $\mathrm{t}$ statistik dari variabel intensitas modal dengan leverage sebagai pemoderasi adalah -3.255730 dengan tingkat signifikan $(0.0013<0,05)$ intensitas modal berpengaruh terhadap penghindaran pajak dengan leverage sebagai pemoderasi. Dengan demikian Ho ditolak dan Ha diterima. Maka dalam penelitian ini leverege memoderasi pengaruh intesitas modal terhadap penghindaran pajak.

Leverage merupakan sumber pendanaan perusahaan eksternal dari hutang, hutang yang dimaksud disini adalah hutang jangka panjang. Menurut Carolina et al (2014) leverage menunjukan sejauh mana aktiva perusahaan bibiayai dengan hutang. Hal ini berarti leverage akan menunjukan perbandingan sumber pembiayaan yang digunakan perusahaan untuk membiayai kegiatan usahanya, antara menggunakan uang dengan mengguanakan modal sendiri.

Semakin tingginya jumlah pendanaan perusahaan dari hutang pihak ketiga yang digunakan perusahaan dan semakin tinggi pula biaya bunga yang timbul. Dengan adanya biaya bunga semakin tinggi akan memberinkan pengaruh berkurangnya laba sebelum pajak perusahaan, maka hal tersebut memberikan pengaruh terhadap beban pajak perusahaan semakin rendah.

Sehingga penggunaan hutang oleh perusahaan dapat digunakan untuk penghematan pajak dengan memperoleh insentif berupa bbeban bunga yang akan menjadi pengurang penghasilan kena pajak. Sehingga pihak manajemen akan memanfaatkan pembiyayaan yang berasal dari hutang agar laba perusahaan akan semakin kecil karena adanya biaya bunga yang besar maka menimbulkan beban pajak perusahaan akan menjadi rendah.

Pengaruh karakteristik perusahaan terhadap penghindaran pajak dengan leverage sebagai pemoderasi

Dari hasil uji t diketahui t statistik variabel karakteristik perusahaan dengan leverage sebagai pemoderasi adalah 3.376772 dengan tingkat signifikan $(0.0009<0,05)$ karakteristik perusahaan berpengaruh terhadap penghinddaran pajak dengan leverage sebagai pemoderasi. Dengan demikian Ho ditolak dan Ha diterima. Maka dalam penelitian ini leverage memoderasi pengaruh karakteristik perusahaan terhadap penghindaran pajak. perusahaan yang besar akan memiliki sumber daya yang besar untuk mempengaruhi proses politik yang dikehendaki dan menguntungkan perusahaan termasuk perencanaan pajak, sehingga mereka dapat melakukan aktivitas penghindaran pajak untuk mencapai optimal penghematan pajak

Sehingga penggunaan hutang oleh perusahaan yang besar dapat digunakan untuk penghematan pajak dengan memperoleh insentif berupa beban bunga yang akan menjadi pengurang penghasilan kena pajak. Sehingga pihak manajemen akan memanfaatkan pembiyayaan yang berasal dari hutang agar laba perusahaan akan semakin kecil karena adanya biaya bunga yang besar maka menimbulkan beban pajak perusahaan akan menjadi rendah.

Pengaruh pengungkapan CSR terhadap penghindaran pajak dengan leverage sebagai pemoderasi

Dari hasil uji t diketahui $\mathrm{t}$ statistik variabel pengungkapan CSR dengan leverage sebagai pemoderasi adalah -1.260615 dengan tingkat signifikan $(0.2088>0,05)$ pengungkapan CSR tidak berpengaruh terhadap penghinddaran pajak dengan leverage sebagai pemoderasi, Dengan demikian Ho diterima dan Ha ditolak. Maka dalam penelitian ini leverage tidak memoderasi pengaruh pengungkapan CSR terhadap penghindaran pajak suatu perusahaan.

Hasil ini menunjukan bahwa perusahaan yang memiliki leverage tinggi akan lebih sedikit mengunkapkan informasi tanggung jawab sosial, supaya dapat melaporkan laba sekarang yang lebih tinggi (mengurangi biaya pengungkapan).

Pengaruh leverage terhadap penghindaran pajak sebagai pemoderasi

Dari hasil uji $\mathrm{t}$ diketahui $\mathrm{t}$ statistik variabel leverage adalah -1.567403 dengan tingkat signifikan $(0.1185>0,05)$ leverage tidak berpengaruh terhadap penghindaran pajak. Dengan demikian Ho diterima dan Ha ditolak. Maka dalam peelitian ini leverage tidak mempengaruhi perusahaan dalam penghindaran pajak. 
Hal ini mencerminkan bahwa perusahaan tidak selalu melakukan pembiayaan yang berasal dari hutang untuk membuat laba perusahaan semakin kecil. Bisa jadi dalam kasus ini perusahaan lebih banyak melakukan pembiayaan dengan modal sendiri sehihingga perusahaan tidak perlu membayarkan beban bunga yang dapat mengurangi pajak penghasilannya. Sehingga perusahaan tidak menggunakan tingkat leverage dalam melakukan penghindaran pajak.

\section{KESIMPULAN}

Penelitian ini menganalisis pengaruh capital intensity, karakteristik perusahaan, dan csr disclosure terhadap penghindaran pajak pada perusahaan manufaktur. Berdasarkan hasil penelitian dan pembahasan yang telah penulis lakukan dapat disimpulkan bahwa intensitas modal dan karakteristik perusahaan berpengaruh signifikan terhadap penghindaran pajak, pada perusahaan manufaktur yang terdaftar di Bursa Efek Indonesia. Semakin besar capital intensity suatu perusahaan, semakin besar pula tingkat penghindaran pajaknya. Penyusutan terjadi sebagai akibat dari investasi perusahaan dalam aset tetap. Biaya tersebut akan dipotong pajak. Ketika capital intensity meningkat, nilai ETR perusahaan turun sebagai akibat dari biaya tambahan. Akibatnya, perusahaan akan lebih agresif dalam memenuhi kewajiban perpajakannya, atau aktivitas penghindaran pajaknya akan meningkat. Sedangkan CSR tidak berpengaruh signifikan terhadap penghindaran pajak. Semakin tinggi tingkat pengungkapan CSR yang dilakukan maka semakin rendah tingkat penghindaran pajaknya. Penelitian ini masih sangat terbatas lingkup pembahasannya. Untuk penelitian selanjutnya, banyak variabel lain yang bisa digunakan untuk menganalisis penghindaran pajak seperti corporate governance, koneksi politik, dan lainnya.

\section{REFERENSI}

Adisamartha, I.B., \& Noviari, N. (2015). Pengaruh Likuiditas, Leverage, Intensitas Persediaan Dan Intensitas Aset Tetap Pada Tingkat Agresivitas Wajib Pajak Badan. E-Jurnal Akuntansi, 13, 973-1000.

Agusti, W. Y. (2014). Pengaruh profitabilitas, leverage, dan corporate governance terhadap tax avoidance (studi empiris pada perusahaan manufaktur yang terdaftar di BEI tahun 2009-2012). Jurnal Akuntansi, 2(3).

Ghozali, I. (2018). Aplikasi Analisis Multivariate Dengan Program IBM SPSS 25, Edisi Kesembilan. Semarang: Penerbit Undip.

Dharma, I., \& Ardiana, P. (2016). Pengaruh Leverage, Intensitas Aset Tetap, Ukuran Perusahaan, Dan Koneksi Politik Terhadap Tax Avoidance. E-Jurnal Akuntansi, 15(1), 584-613. Retrieved from https://ojs.unud.ac.id/index.php/Akuntansi/article/view/17463

Dharma, N. B. S., \& Noviari, N. (2017). Pengaruh Corporate Social Responsibility dan Capital Intensity Terhadap Tax Avoidance. E-Jurnal Akuntansi Universitas Udayana, 18(1), 529-556.

Dwilopa, D. E., \& Jatmiko, B. (2016). Pengaruh Corporate Social Responsibility, Capital Intensity, dan Perencanaan Pajak terhadap Penghindaran Pajak. Jurnal. Yogyakarta: Universitas Muhammadiyah Yogyakarta.

Lanis, R., \& Richardson, G. (2012). Corporate social responsibility and tax aggressiveness: An empirical analysis. Journal of Accounting and Public Policy, 31(1), 86-108.

Lanis, R., \& Richardson, G. (2013). Corporate social responsibility and tax aggressiveness: a test of legitimacy theory. Accounting, Auditing \& Accountability Journal.

Maharani, I. G. A. C., \& Suardana, K. A. (2014). Pengaruh corporate governance, profitabilitas dan karakteristik eksekutif pada tax avoidance perusahaan manufaktur. E-Jurnal Akuntansi Universitas Udayana, 9(2), 525-539.

Nurjannah, N. (2017). Pengaruh Konservatisme Akuntansi dan Intensitas Modal (Capital Intensity) terhadap Penghindaran Pajak (Tax Avoidance) dengan Dewan Komisaris Independen sebagai Variabel Moderating (Studi pada Perusahaan Perbankan Yang Terdaftar Di Bursa Efek Indonesia) (Doctoral dissertation, Universitas Islam Negeri Alauddin Makassar). 
Ningrum, A. K., Suprapti, E., \& Anwar, A. S. H. (2018). Pengaruh Pengungkapan Corporate Social Responsibility Terhadap Tax Avoidance Dengan Gender Sebagai Variabel Moderasi (Studi Empiris Pada Perusahaan Manufaktur Yang Terdaftar Di Bursa Efek Indonesia Tahun 2016). BALANCE: Economic, Business, Management and Accounting Journal, 15(01).

Okrayanti, T. Y., Utomo, S. W., \& Nuraina, E. (2017). Pengaruh Karakteristik Perusahaan dan Corporate Governance Terhadap Tax Avoidance. E-Jurnal Akuntansi Universitas Pgri Madiun.

Panjaitan, I. (2016). Pengaruh Leverage Dan Firm Size Terhadap Penghindaran Pajak (Tax Avoidence) Pada Perusahaan Property Dengan Profitabilitas Sebagai Variabel Moderating. Media Manajemen Jasa, 2(2).

Putri, V. R., \& Putra, B. I. (2017). Pengaruh Leverage, Profitability, Ukuran Perusahaan Dan Proporsi Kepemilikan Institusional Terhadap Tax Avoidance. Jurnal Manajemen Dayasaing, 19(1), 1-11.

Rahma, A. A., \& Aldi, F. (2020). Effect of foreign commissioners, ethnic commissioners, feminism commissioners towards csr disclosure. Assets: Jurnal Akuntansi Dan Pendidikan, 9(1), 16-29.

Rahma, A. A., \& Aldi, F. . (2020). The Importance of Commissioners Board Diversity in CSR Disclosures. International Journal of Economics Development Research (IJEDR), 1(2), 136149. https://doi.org/10.37385/ijedr.v1i2.66

Resmi, Siti. (2013). Perpajakan ; Teori dan Kasus (Ed. VII buku I). JAKARTA: Salemba Empat.

Sari, N. A. (2018). Pengaruh profitabilitas dan leverage terhadap penghindaran pajak dengan CSR sebagai variabel pemoderasi: Studi pada perusahaan sektor industri barang konsumsi yang terdaftar di BEI tahun 2014-2016 (Doctoral dissertation, Universitas Islam Negeri Maulana Malik Ibrahim).

Suyanto, K. D., \& Supramono, S. (2012). Likuiditas, leverage, komisaris independen, dan manajemen laba terhadap agresivitas pajak perusahaan. Jurnal Keuangan dan Perbankan, 16(2).

Waluyo, B. I. Wirawan. 2003. Perpajakan Indonesia. 